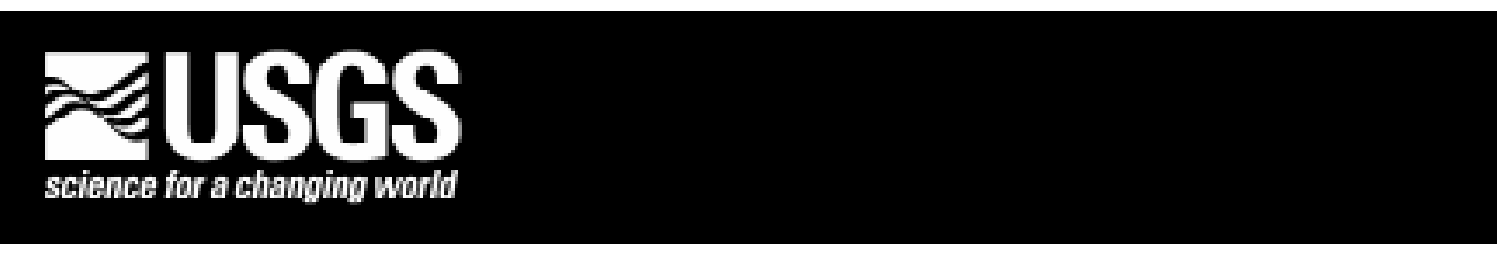

\title{
Digital Mining Claim Density Map for Federal Lands in Oregon: 1996
}

\author{
by Paul C. Hyndman ${ }^{1}$ and Harry W. Campbell ${ }^{2}$
}

Open-File Report 99-541

Version 1.0

1999

This report is preliminary and has not been reviewed for conformity with U.S. Geological Survey editorial standards. Any use of trade, product, or firm names is for descriptive purposes only and does not imply endorsement by the U.S. Government.

This digital map, identified as "Digital Mining Claim Density Map for Federal Lands in Oregon: 1996," has been approved for release and publication by the Director of the USGS. Although the digital map has been reviewed and is substantially complete, the USGS reserves the right to revise the data pursuant to further analysis and review. The databases are released on condition that neither the USGS nor the U.S. Government may be held liable for any damages resulting from their use.

Manuscript approved November 8, 1999

\section{U.S. DEPARTMENT OF THE INTERIOR \\ U.S. GEOLOGICAL SURVEY}

\footnotetext{
${ }^{1}$ U.S. Geological Survey, Spokane, WA 99201

${ }^{2}$ Retired, U.S. Geological Survey, Spokane, WA 99201
} 


\section{TABLE OF CONTENTS}

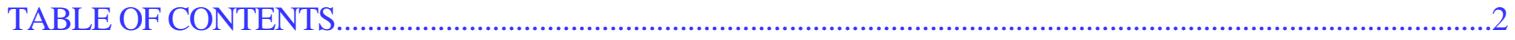

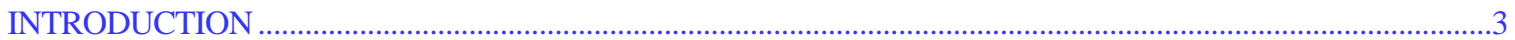

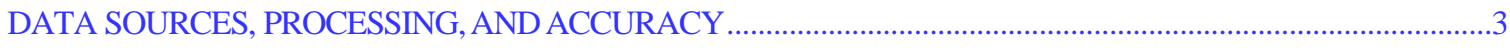

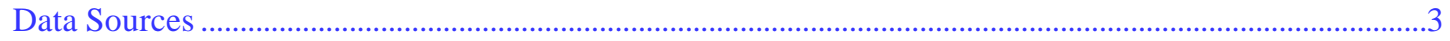

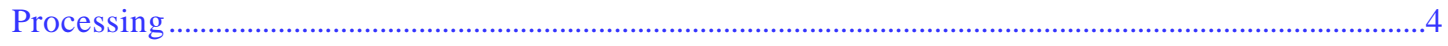

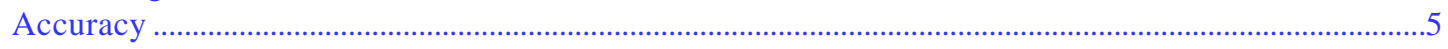

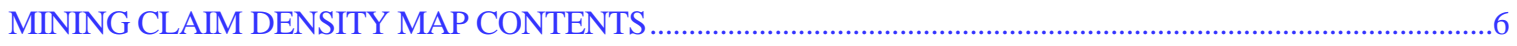

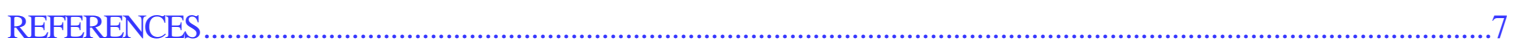

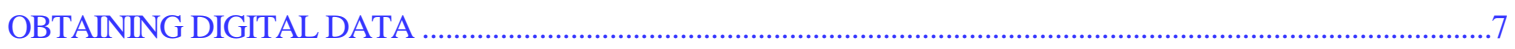

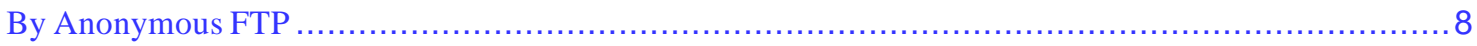

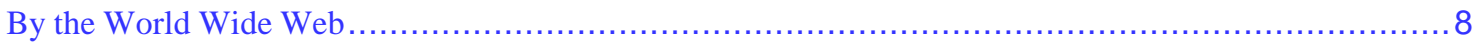

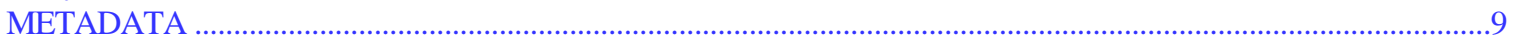

Description of SINGLE precision coverage or_clms ................................................................................

Description of Arc/Info or_clms.rel relate structure ..................................................................................

Formal metadata for the mine claim density map and associated files ......................................................10

Figure 1. --- Open (black) and closed (gray) status of mining claims in Oregon for 1996..................................

Table 1. Mining claim totals by type and status in Oregon (database linked to digital map) ..............................

Table 2. Mining claim totals by type and status in Oregon (or_clms.clms database)..........................................5

Table 3. Field structure and descriptions of specific fields for the digital map ..................................................6

Table 4. Field structure and descriptions for the mine claim density database..................................................

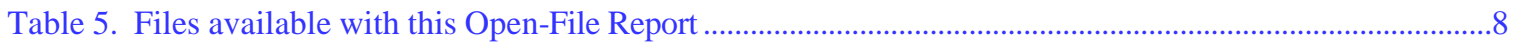




\title{
INTRODUCTION
}

This report describes a digital map generated by the U.S. Geological Survey (USGS) to provide digital spatial mining claim density information for federal lands in Oregon as of March 1997. Mining claim data is earth science information deemed to be relevant to the assessment of historic, current, and future ecological, economic, and social systems. There is no paper map included in this Open-File report.

In accordance with the Federal Land Policy and Management Act of 1976 (FLPMA), all unpatented mining claims, mill and tunnel sites must be recorded at the appropriate Bureau of Land Management (BLM) State office. BLM maintains a cumulative computer listing of mining claims in the Mining Claim Recordation System (MCRS) database with locations given by meridian, township, range, and section. A mining claim is considered closed when the claim is relinquished or a formal BLM decision declaring the mining claim null and void has been issued and the appeal period has expired. All other mining claims filed with BLM are considered to be open and actively held. The digital map (figure 1.) with the mining claim density database available in this report are suitable for geographic information system (GIS)-based regional assessments at a scale of 1:100,000 or smaller.

\section{DATA SOURCES, PROCESSING, AND ACCURACY}

\section{Data Sources}

The mining claim density database of federal lands in Oregon is one of 13 statewide databases published in the U.S. Geological Survey Open-File Report 99-325. The database contains information identifying 1) the meridian, township, range, and section (MTRS) designation, a unique record identifier, 2) the number and type of claims (lode, placer, mill site, tunnel site) within each section, and 3) the status of the claims (open is held by a claimant, closed is no longer held). The original mine claim data used to create the databases in OF99-325 were acquired from the BLM in March 1997. An official quarterly release of the MCRS mine claim data for Oregon is available by specific request from the:

\author{
United States Department of the Interior \\ Bureau of Land Management \\ Mining Claim Recordation System Coordinator \\ NI-112, Denver Federal Center \\ P.O. Box 25047 \\ Denver, CO 80225-0047
}

The statewide Public Land Survey (PLS) digital map of Oregon, pls.e00, was used to create the digital mining claim density map. The digital map was in Arc/Info export format and is available on the Internet at URL http://www.sscgis.state.or.us/data/themes.html or by specific request from the:

State Service Center for GIS

Department of Administrative Services

155 Cottage St. NE

Salem, OR 97310 


\section{Processing}

The digital file, pls.e00, was imported using Arc/Info, version 7.1.1 (Environmental Systems Research Institute, Inc., Redlands, California), a commercially available GIS software, as an Arc/Info coverage into a workspace on a Sun Ultra 1 with Solaris 2.5.1 operating software. Each section of the digital PLS was given a unique section identifier corresponding in form to the MTRS in the mining claim density database, blm_id.dbf. The mining claim density database from OF99-325 was imported as an Info file and linked, using a relate file, with the digital PLS of Oregon. The linking process connected the data in the database to their corresponding sections in the digital map. The result was a digital mining claim density map (figure 1) with the attributes of the current database. The relate file was named or_clms.rel and the database of Oregon from OF99-325 was renamed or_clms.clms. The renaming allows the database and the relate file to be included in the single export file, or_clms.e00, created when packaging the digital map for others.

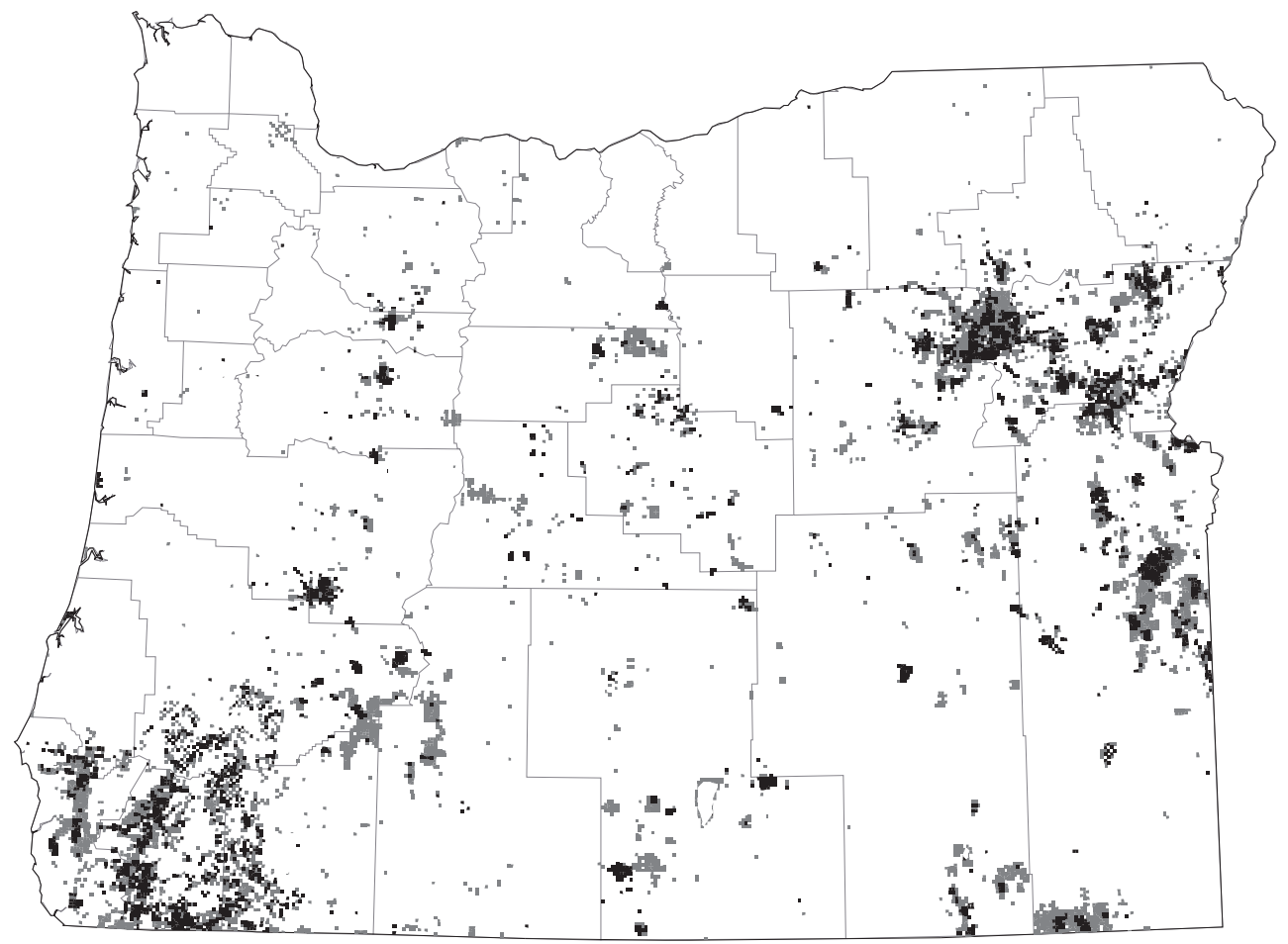

Figure 1. --- Open (black) and closed (gray) status of mining claims in Oregon for 1996.

Figure 1 displays the sections of the PLS containing claims and their status for this digital map. The map can be queried regarding its other attributes and can be used in investigating relationships with other digital data. 


\section{Accuracy}

Several factors can affect the accuracy of the mining claim density database and digital map. The original data from BLM may contain errors. Two possible sources of error in the database are 1) incorrect position of the mining claim submitted by the claimant, and 2) input errors from the data entry papers to the computer database.

The digital map of the PLS of Oregon may contain errors. Possible errors include 1) misidentified sections, 2) sections with no identifying information, and 3) sections missing from the PLS digital map. These errors would result in incorrect locations of the mining claim density data or failure of the data to be connected with the digital map.

Tables 1 and 2 summarize the number of mining claims by type and status for the digital map and the database. The total number of claims in the digital map (table 1) does not agree with the total number of claims in the mining claim density database from OF99-325 (table 2). Some contributing factors may be 1) failure of the data to find a section to combine with in the digital map, or 2) sections occurring as multiple parts due to irregular state boundaries, shorelines, or to non-PLS land surveys. The first type of error results in a decrease in the expected number of claims in the digital map. The second results in an increase. The digital map does contain sections with multiple parts. A ratio of the grand totals of all claims of Table 1 to Table 2 should show the degree of fit of the digital map totals to the original database totals. A value equal to 1 indicates a $100 \%$ fit. A value less than 1 indicates data was lost. A value greater than 1 indicates multi-part sections may be in the digital PLS map. The table shows that the digital map contains 100205 mining claims but the database contains 100207 mining claims. The ratio of the two numbers, 0.99998, indicates a very good fit.

Table 1. Mining claim totals by type and status in Oregon (database linked to digital map)

\begin{tabular}{||l|c|c|c|c|c||}
\hline \hline & \multicolumn{5}{|c||}{ DIGITAL MAP DATABASE CLAIM TOTALS } \\
\hline \multicolumn{1}{|c|}{ Type of Claim } & LODE & PLACER & MILL & TUNNEL & ALL CLAIMS \\
\hline $\begin{array}{l}\text { Number of Open } \\
\text { Mining Claims }\end{array}$ & 12211 & 5430 & 178 & 38 & 17857 \\
\hline $\begin{array}{l}\text { Number of Closed } \\
\text { Mining Claims }\end{array}$ & 60615 & 21235 & 293 & 205 & 82348 \\
\hline Grand Totals & 72826 & 26665 & 471 & 243 & 100205 \\
\hline \hline
\end{tabular}

Table 2. Mining claim totals by type and status in Oregon (or_clms.clms database)

\begin{tabular}{||l|c|c|c|c|c||}
\hline \hline & \multicolumn{5}{|c||}{ DENSITY DATABASE CLAIM TOTALS } \\
\hline \multicolumn{1}{|c|}{ Type of Claim } & LODE & PLACER & MILL & TUNNEL & ALL CLAIMS \\
\hline $\begin{array}{l}\text { Number of Open } \\
\text { Mining Claims }\end{array}$ & 12217 & 5418 & 178 & 38 & 17851 \\
\hline $\begin{array}{l}\text { Number of Closed } \\
\text { Mining Claims }\end{array}$ & 60524 & 21334 & 293 & 205 & 82356 \\
\hline Grand Totals & 72741 & 26752 & 471 & 243 & 100207 \\
\hline \hline
\end{tabular}

Another concern regarding accuracy involves the visual representation of the data to a viewer. The digital map does not accurately represent the aerial extent of the lands covered by a mining claim because the presence of one mining claim, about 20 acres for a lode claim, will 'color in' the entire section (typically 640 acres or 1 square mile) it occurs in. The visual representation of one claim is magnified by a factor of 
32 times its actual size. The best digital map resolution available at this time is to the section. Any area calculations done with the digital map for mining claims will likely be unreliable. Specific information about a particular area should be acquired from the BLM State office.

Additionally, the positional accuracy of a mining claim is generalized to one section in the PLS even if it crosses into another section. Mining claims generally follow geologic features and usually do not conform to the PLS lines. The procedure used by Campbell (1996) chooses the first section listed for a mining claim in the MCRS as the section of position. This method insures that each claim is counted only once. The digital PLS map is considered accurate enough for geographic representations for the purposes of regional assessments at a scale of 1:100,000 or smaller.

\section{MINING CLAIM DENSITY MAP CONTENTS}

Table 3 lists the structure and descriptions of specific fields within the digital map, or_clms. Table 4 contains the structure and descriptions of specific fields within the mining claim density database, or_clms.clms. The italicized field in bold type, $\boldsymbol{m t r s}$, is common to both the PLS and the database and is used by the relate file to link the database to the digital map.

Table 3. Field structure and descriptions of specific fields for the digital map

\begin{tabular}{||c|c|c|c|l|l|l||}
\hline \hline COLUMN & ITEM NAME & WIDTH & OUTPUT & TYPE & DEC & DESCRIPTION \\
\hline 1 & area & 4 & 12 & Floating & 3 & Internal Arc/Info polygon area \\
\hline 5 & perimeter & 4 & 12 & Floating & 3 & Internal Arc/Info polygon perimeter \\
\hline 9 & or_clms\# & 4 & 5 & Binary & - & Internal Arc/info polygon number \\
\hline 13 & or_clms-id & 4 & 5 & Binary & - & User-defined polygon number \\
\hline 17 & township & 5 & 5 & Numeric & 2 & Township designation \\
\hline 22 & twp.char & 1 & 1 & Character & - & Township direction - North or South \\
\hline 23 & range & 5 & 5 & Numeric & 2 & Range designation \\
\hline 29 & rng.char & 1 & 1 & Character & - & Range direction - East or West \\
\hline 31 & section & 2 & 2 & Integer & - & Section number \\
\hline 34 & dlc & 3 & 3 & Integer & - & Donation land claim \\
\hline 38 & y-coord & 4 & 12 & Floating & 3 & X coordinate for center of section \\
\hline 42 & ytrs ${ }^{1}$ & 18 & 18 & Character & - & Meridian+Township+Range+Section \\
\hline 17 & loc-dlc & 17 & 17 & Character & - & $\begin{array}{l}\text { Township+twp.char+range+rng.char+ } \\
\text { Dlc (redefined field) }\end{array}$ \\
\hline 17 & tr & 12 & 12 & Character & - & Township + range (redefined field) \\
\hline 17 & loc-info & 14 & 14 & Character & - & $\begin{array}{l}\text { Township+twp.char+range+rng.char+ } \\
\text { Section (redefined field) }\end{array}$ \\
\hline \hline
\end{tabular}

\footnotetext{
${ }^{1}$ For example, '33 30.0S 29.2E05' is Meridian 33, Township 30 South, Range 29 1/2 East, Section 5

Oregon contains the Willamette Meridian (33).
} 
Table 4. Field structure and descriptions for the mine claim density database

\begin{tabular}{||c|c|c|c|l|c|l||}
\hline \hline COLUMN & ITEM NAME & WIDTH & OUTPUT & TYPE & DEC & DESCRIPTION \\
\hline 1 & mtrs $^{1}$ & 18 & 18 & Character & - & Meridian+Township+Range+Section \\
\hline 19 & nolc $^{2}$ & 4 & 4 & Binary & - & Number of Open Lode Claims \\
\hline 23 & nopc & 4 & 4 & Binary & - & Number of Open Placer Claims \\
\hline 31 & nomc & 4 & 4 & Binary & - & Number of Open Mill site Claims \\
\hline 35 & notc & 4 & 4 & Binary & - & Number of Open Tunnel Claims \\
\hline 39 & toc & 4 & 4 & Binary & - & Total number of Open Claims \\
\hline 43 & nclc & 4 & 4 & Binary & - & Number of Closed Lode Claims \\
\hline 47 & ncpc & 4 & 4 & Binary & - & Number of Closed Placer Claims \\
\hline 51 & nctc & 4 & 4 & Binary & - & Number of Closed Mill site Claims \\
\hline 55 & tcc & 4 & 4 & Binary & - & Number of Closed Tunnel Claims \\
\hline 59 & tc & 4 & 4 & Binary & - & Total number of Closed Claims \\
\hline \hline
\end{tabular}

${ }^{1}$ For example, '33 30.0S 29.2E05' is Meridian 33, Township 30 South, Range 29 1/2 East, Section 5

Oregon contains the Willamette Meridian (33).

2 in a section of the PLS

\section{REFERENCES}

Campbell, Harry W., 1996, Procedure for making a mining claim density map from BLM claim recordation digital data: U.S. Geological Survey Open-File Report 96-736, 13 p.

Hyndman, Paul C. and Harry W. Campbell, 1999, Digital databases containing mining claim density information for Arizona, California, Colorado, Idaho, Montana, Nebraska, New Mexico, Nevada, Oregon, South Dakota, Utah, Washington, and Wyoming created from the BLM Mining Claim Recordation System: 1996: U.S. Geological Survey Open-File Report 99-325, 21 p.

State Service Center for GIS, 1994, Coverage PLS -- Public Land Survey: Oregon Department of Administrative Services digital map PLS.E00.

\section{OBTAINING DIGITAL DATA}

The digital mining claim density map of Oregon, or_clms, is provided with this report in Arc/Info EXPORT format as or_clms.e00. The mining claim density database, or_clms.clms, and the relate file, or_clms.rel, are contained in the export file. A metadata file, or_clms.met, occurs separately. These files and this report are available from the USGS public access FTP site and the World Wide Web site on the Internet. Table 5 lists the files and their sizes. 
Table 5. Files available with this Open-File Report

\begin{tabular}{||c|c|c||}
\hline FILE NAME & FILE TYPE & SIZE IN KILOBYTES \\
\hline of_or.pdf & PDF document & 326 \\
\hline or_clms.e00 & Arc/Info export & 7,568 \\
\hline or_clms.met & Metadata & 35 \\
\hline
\end{tabular}

\section{By Anonymous FTP}

Do the following steps to obtain the files for OF99-541by anonymous ftp. Windows users may need to start FTP in the MSDOS window.

STEP (type the words between the quotes)

cd to your_local_directory

'ftp wrgis.wr.usgs.gov'

Name: 'anonymous'

Password: your email address

'cd pub/open-file'

'cd of 99-541'

'binary'

'get of99-541.exe'

'bye'

\section{REASON}

Go to a directory to receive the WinZip file - you may need to make a directory first Make ftp connection with the USGS computer, WRGIS

Use 'anonymous' as your user name Use your email address as a password (you@email_address)

Go down to the pub/open-file directory Go down to the specific open file directory Type the word 'binary' to change the transfer type to binary mode Copy the self-extracting file across the Internet to the receiving directory on your computer Close the ftp connection

Extracting the files from the of99-541.exe self-extracting file is accomplished by typing the name of the file, 'of99-541', and pressing the 'Enter' key. The files will unload automatically.

\section{By the World Wide Web}

The files for this report can be obtained over the Internet at URL http://wrgis.wr.usgs.gov/open-file/. Do the following steps to obtain the files for OF99-541 by the World Wide Web:

\section{STEP}

Attach to the internet with your web browser 'http://wrgis.wr.usgs.gov/docs/northwest_region/ index.html'

Find the report in the listing and click on 'Click here for digital files'

Follow the instructions for downloading the data and this report

\section{REASON}

This connects you to the internet.

Make sure the internet address looks like this to connect with the USGS computer, WRGIS

This opens a page with instructions and information for downloading the report

You should receive the report to your computer 


\section{METADATA}

Following are 1) an Arc/Info description of the digital map, or_clms, 2) a description of the relate file, and 3 ) the formal metadata for the digital map and associated files.

\section{Description of SINGLE precision coverage or_clms}

\begin{tabular}{|c|c|c|c|c|c|}
\hline \multirow[b]{2}{*}{ Feature Class } & \multicolumn{3}{|c|}{ FEATURE CLASSES } & \multirow[b]{2}{*}{$\begin{array}{l}\text { Spatial } \\
\text { Index? }\end{array}$} & \multirow[b]{2}{*}{ Topology? } \\
\hline & Subclass & $\begin{array}{l}\text { Number of } \\
\text { Features }\end{array}$ & $\begin{array}{l}\text { Attribute } \\
\text { data (bytes) }\end{array}$ & & \\
\hline ARCS & & 20563 & & & \\
\hline POLYGONS & & 7191 & 60 & & Yes \\
\hline NODES & & 14143 & & & \\
\hline
\end{tabular}

SECONDARY FEATURES

Tics

320

Arc Segments 26510

Polygon Labels 7011

TOLERANCES

Fuzzy $=205.5 \mathrm{~V}$

COVERAGE BOUNDARY

Dangle $=0.000 \mathrm{~N}$

$\mathrm{Xmin}=241587.141$

$X \max =2296582.250$

$\mathrm{Ymin}=88890.555$

$Y \max =1563227.250$

STATUS

The coverage has not been Edited since the last BUILD or CLEAN

\section{COORDINATE SYSTEM DESCRIPTION}

\begin{tabular}{ll} 
Projection & LAMBERT \\
Datum & NAD83 \\
Units & 3.28084 \\
Spheroid & GRS1980 \\
Parameters: & \\
\multicolumn{1}{l}{$1^{\text {ST }}$ standard parallel } & 43000.000 \\
$\quad 2^{\text {nd }}$ standard parallel & 45300.000 \\
$\quad$ central meridian & -120300.000 \\
$\quad$ latitude of projection's origin & 41450.000 \\
$\quad$ false easting (meters) & 400000.0000 \\
$\quad$ false northing (meters) & 0.00000
\end{tabular}

Description of Arc/Info or_clms.rel relate structure

$\begin{array}{ll}\text { Relation } & =\text { OR_CLMS } \\ \text { Table-Id } & =\text { or_clms.clms }\end{array}$ 


$\begin{array}{ll}\text { Database } & =\text { info } \\ \text { Item } & =\text { MTRS } \\ \text { Column } & =\text { mtrs } \\ \text { Type } & =\text { ORDERED } \\ \text { Access } & =\text { RO }\end{array}$

\section{Formal metadata for the mine claim density map and associated files}

The following metadata describes the mining claim density map:

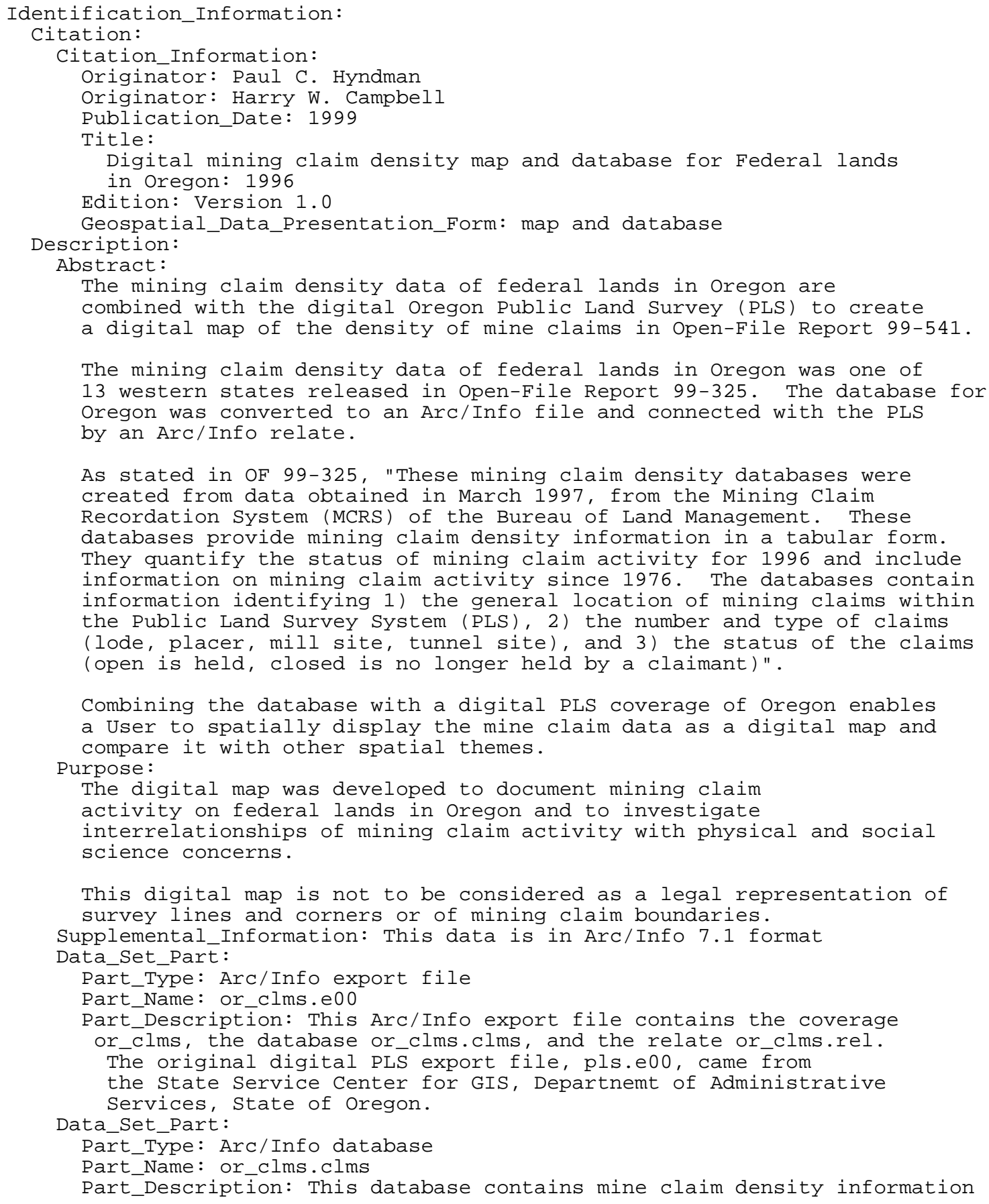


for federal lands in the state, from 1976 through 1996. It is one of several state databases from OF 99-325.

Data_Set_Part:

Part_Type: Arc/Info relate

Part_Name: or_clms.rel

Part Description: This file contains the parameters needed to relate the database, or_clms.clms to the digital map database, or_clms.pat. The structure of the relate is:
RELATION
$=$ OR_CLMS

TABLE-ID

DATABASE

$=$ or_clms.clms

ITEM

$=$ info

COLUMN

$=$ MTRS

$=\operatorname{mtrs}$

TYPE

$=$ ORDERED

ACCESS

$=\mathrm{RO}$

Time_Period_of_Content:

Time_Period_Information:

Range_of_Dates/Times:

Beginning_Date: 1976

Ending_Date: 1997

Currentness_Reference: Release date of data by the Bureau of Land

Management in March, 1997

Status:

Progress: Complete

Maintenance_and_Update_Frequency: None planned

Spatial_Domain:

Bounding_Coordinates:

West_Bounding_Coordinate: $-124 \quad 3000$

East_Bounding_Coordinate: -1163000

North_Bounding_Coordinate: 461500

South_Bounding_Coordinate: 420000

Keywords:

Theme:

Theme_Keyword_Thesaurus: None

Theme_Keyword: mining claim density

Theme_Keyword: lode

Theme_Keyword: placer

Theme_Keyword: mill site

Theme_Keyword: tunnel site

Theme_Keyword: mine claim

Place:

Place_Keyword_Thesaurus: None

Place_Keyword: Oregon

Access_Constraints: None

Use_Constraints:

Users should contact the BLM for current data. The U.S. Geological Survey

makes no warranties related to the accuracy of the data and users are

required to determine suitability of use for any particular purpose.

This digital map is not to be construed as a legal

representation of mining claim boundaries. The PLS data is from 1:100,000 scale base maps. The map should not be used at scales

larger than 1:100,000.

The user must obtain current information on mining claims from the Oregon State Office of the Bureau of Land Management for the area of interest since the mining claim density data is not current. The information in the database does not provide the legal location or status of individual mining claims.

Any hardcopies utilizing this data set shall clearly indicate their source. If the user has modified the data in any way they are obligated to describe the types of modifications they have performed on the hardcopy map. User specifically agrees not to misrepresent this data set, nor to imply that changes they made were approved by the U.S. Geological Survey.

Point_of_Contact:

Contact_Information:

Contact_Person_Primary:

Contact_Person: Paul Hyndman

Contact_Organization: U.S. Geological Survey

Contact_Position: Geologist 


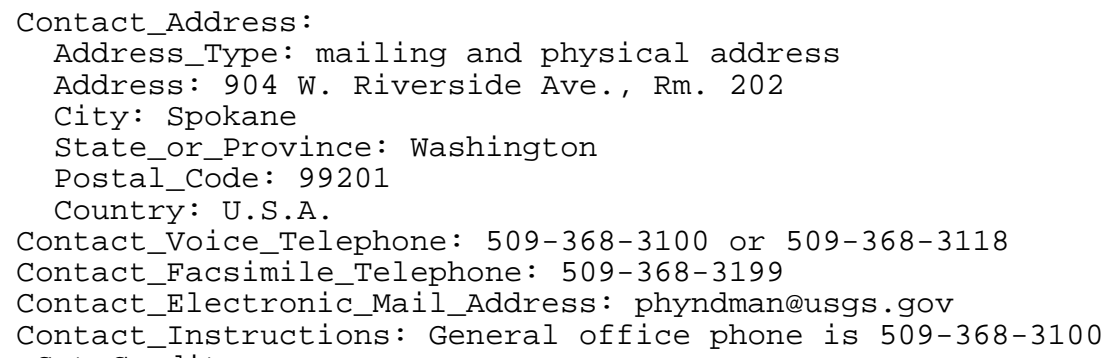

The digital PLS map of Oregon came from the State Service Center for GIS, Department of Administrative Services, State of Oregon

Native_Data_Set_Environment: Solaris 2.5.1, Sun Ultra 1, Arc/Info 7.1.2 Data_Quality_Information:

Attribute_Accuracy:

Attribute_Accuracy_Report:

OF 99-325 reports that the attributes of the mining claim data from BLM

data, claims per section, do not represent the exact number of claims in each section. Some claims overlap into adjoining sections and/or

townships. In order to count each claim only once, it was necessary to choose one section for each claim to be identified with. Therefore, the first section listed in the BLM database for a particular claim was chosen as the section the claim was counted in.

The accuracy was tested by summing each category of claim in the mining claim database and comparing the sum to those from the original BLM database. The sums for each category matched.

No attempt was made to determine the accuracy of BLM's database. Completeness_Report:

None of the data from BLM was omitted. The data is considered complete for the purpose of determining mining claim density in this state.

Logical_Consistency_Report: The data set is a derived subset of the original BLM data. No modifications to the BLM data were made.

Positional_Accuracy: Horizontal_Positional_Accuracy:

Horizontal_Positional_Accuracy_Report:

A claim may be within a section or it may straddle two, three, or four sections. In order to count each claim only once, it was necessary to choose one section for each claim to be identified with. Therefore, the first section listed in the BLM database for a particular claim was chosen as the section the claim was Lineage: counted in.

Source_Information:

Source Citation:

Citation_Information:

Originator: U.S. Geological Survey

Publication Date: 1999

Title: Digital databases containing mining claim density information for Arizona, California, Colorado, Idaho, Montana, Nebraska, New Mexico, Nevada, Oregon, South Dakota, Utah, Washington, and Wyoming created from the BLM Mining Claim Recordation System: 1996 Edition: 1

Geospatial_Data_Presentation_Form: tabular database

Series_Information: Series_Name: Open-File Report Issue Identification: OF 99-325

Publication_Information: Publication Place: Denver, Colorado Publisher: U.S. Geological Survey Other_Citation_Details: 


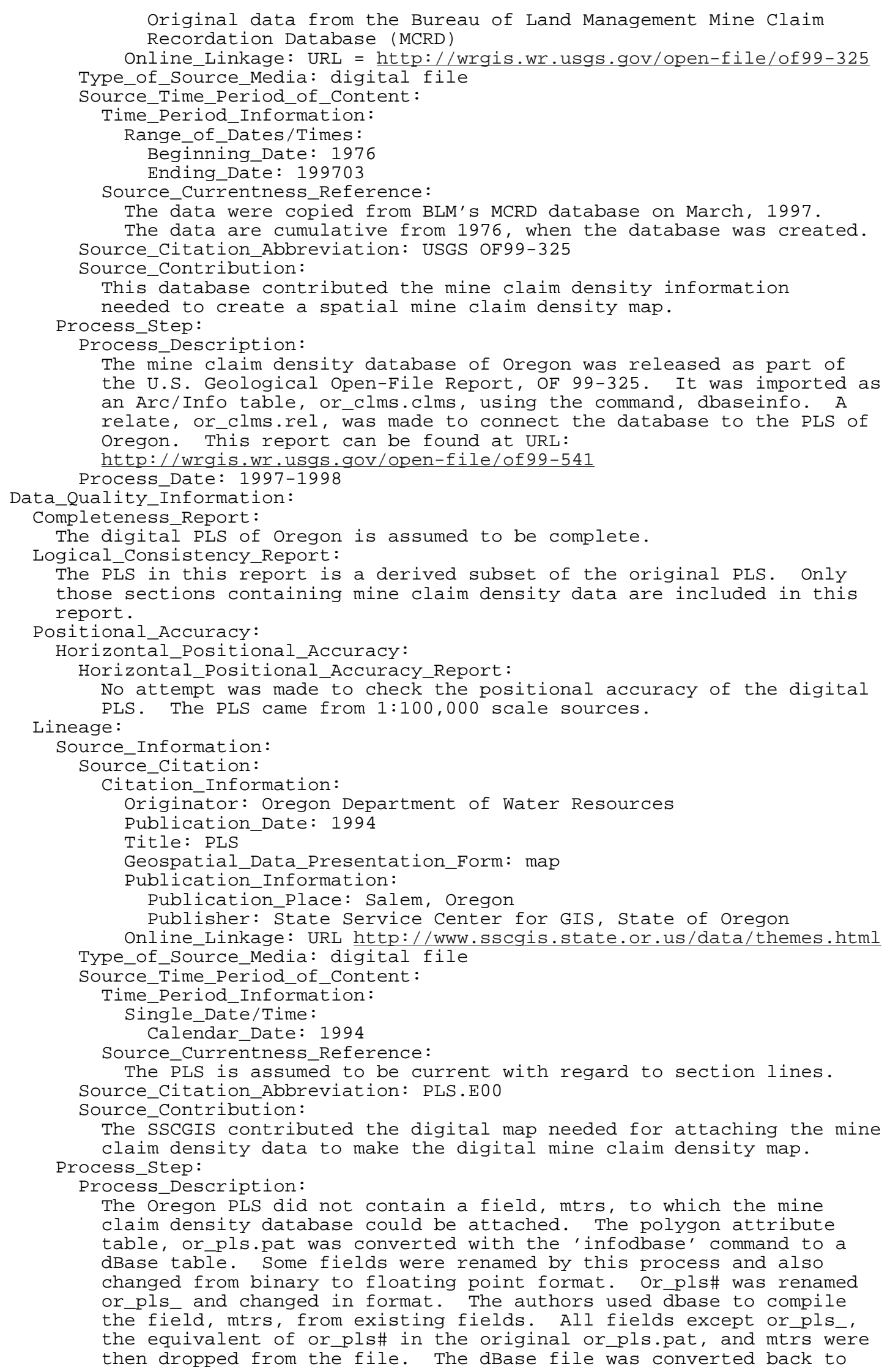


an info file using the 'dbaseinfo' command. A field named or_pls\#, in binary format, was added to match the structure of or_pls\# in or_pls.pat. This field was populated with the values of or_pls_ which made it identical to the original or_pls\# in or_pls.pat. The field, or_pls_ was then dropped from the file and only or_pls\# and mtrs remained. The mtrs field was joined to the original or_pls.pat by using the command 'joinitem' with the common field being or_pls\#. The data from or_clms.clms was linked through the use of a relate, or_clms.rel. An example of commands for using the relate in ArcEdit for selecting all claims in the Total claims (tc) field is:

'restore relate or_clms.rel'

'editcover or_clms'

'sel or_clms//tc > 0 '

Process_Date: 1997

Spatial_Data_Organization_Information:

Direct_Spatial_Reference_Method: Vector

Point_and_Vector_object_Information:

SDTS_Terms_Description:

SDTS_Point_and_Vector_object_Type: Point

Point_and_Vector_object_Count: 14143

SDTS_Point_and_Vector_object_Type: String

Point_and_Vector_object_Count: 20563

SDTS_Point_and_Vector_object_Type: GT-polygon composed of chains

Point_and_Vector_object_Count: 7191

Spatial_Reference_Information:

Horizontal_Coordinate_System_Definition:

Planar:

Map_Projection:

Map_Projection_Name: Lambert Conformal Conic

Lambert_Conformal_Conic:

Standard_Parallel: 43.0

Standard_Parallel: 45.5

Longitude_of_Central_Meridian: -119.5

Latitude_of_Projection_Origin: 41.75

False_Easting: 400000.0000

False_Northing: 0.0000

Planar_Coordinate_Information:

Planar_Coordinate_Encoding_Method: coordinate pair

Planar_Distance_Units: meters

Geodetic_Model:

Horizontal_Datum_Name: North American Datum of 1983

Ellipsoid_Name: Geodetic Reference System 80

Entity_and_Attribute_Information:

Detailed_Description:

Entity_Type:

Entity_Type_Label: or_clms.clms

Entity_Type_Definition:

Summary of values for number and type of mining claims in each section from OF 99-325. The data is tied to an MTRS code which represents the Meridian + Township + Range + Section. This code provides a unique identifier for each Section of the PLS.

Entity_Type_Definition_Source:

The Bureau of Land Management is the official

source for PLS designations and surveys and for

the mining claim data.

Attribute:

Attribute_Label: MTRS

Attribute_Definition:

A concatenation of Meridian, Township, Range, and

Section of the PLS

Attribute_Definition_Source: Bureau of Land Management

Attribute_Domain_Values:

Enumerated_Domain:

Enumerated_Domain_Value: MMTTT.TDRRR.RESS

Enumerated_Domain_Value_Definition:

MTRS is an 18-character field which is a concatenation of meridian (M), Township (T), township direction (D), range (R), range direction (E), and section (S). The form of the field is MMTTT.TDRRR.RESS_. The last two spaces were included in the beginning of the study but were not utilized. 


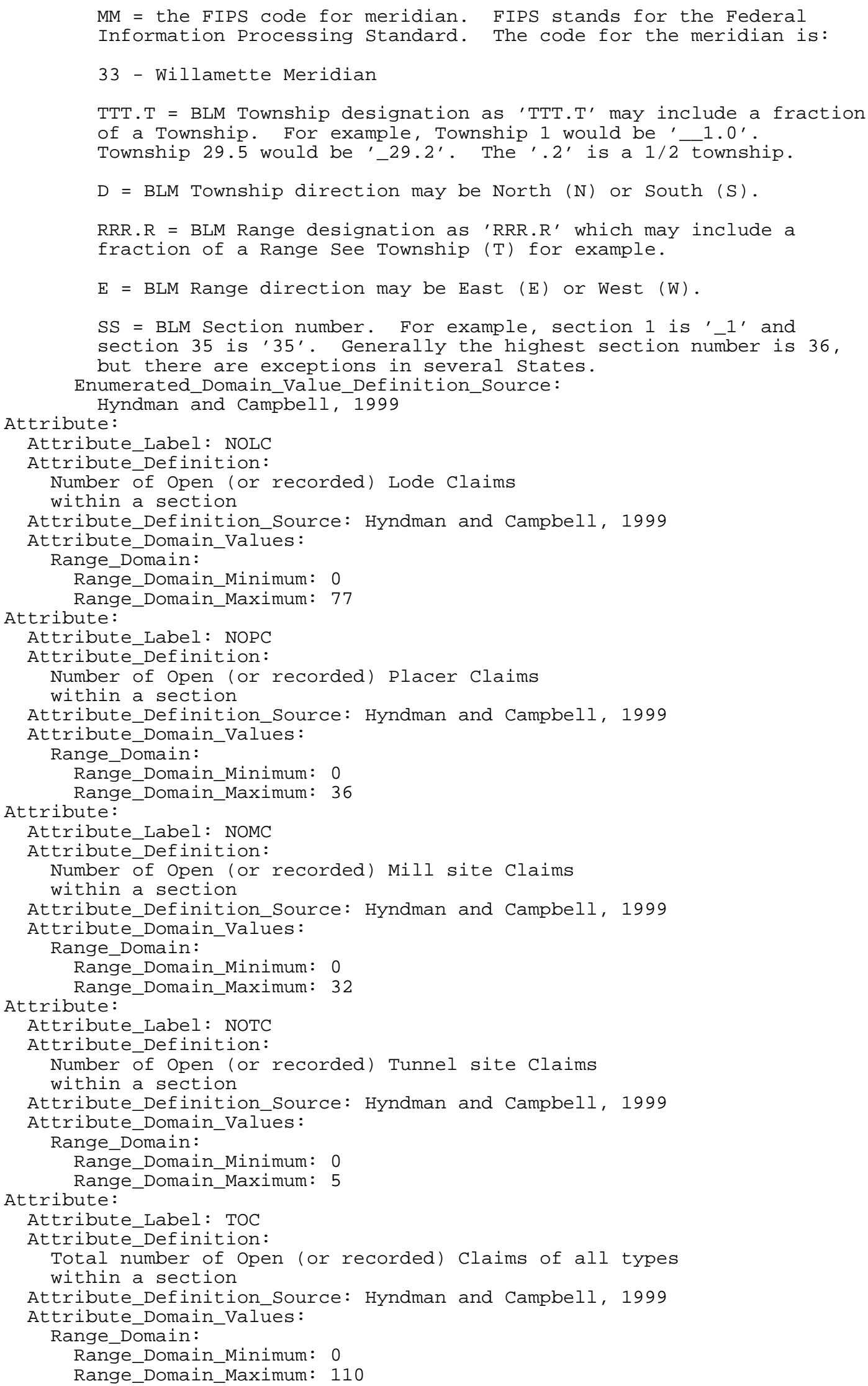




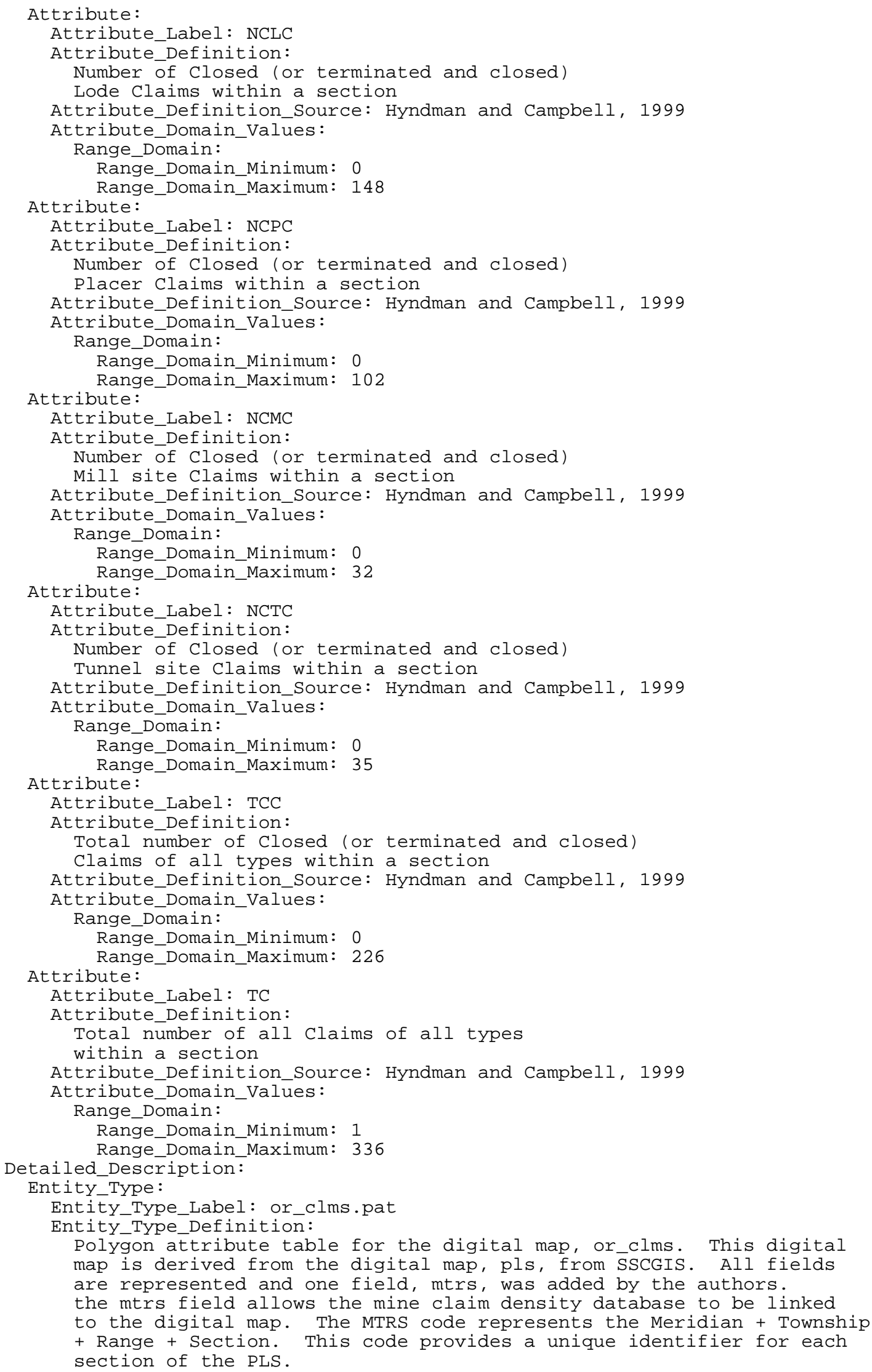




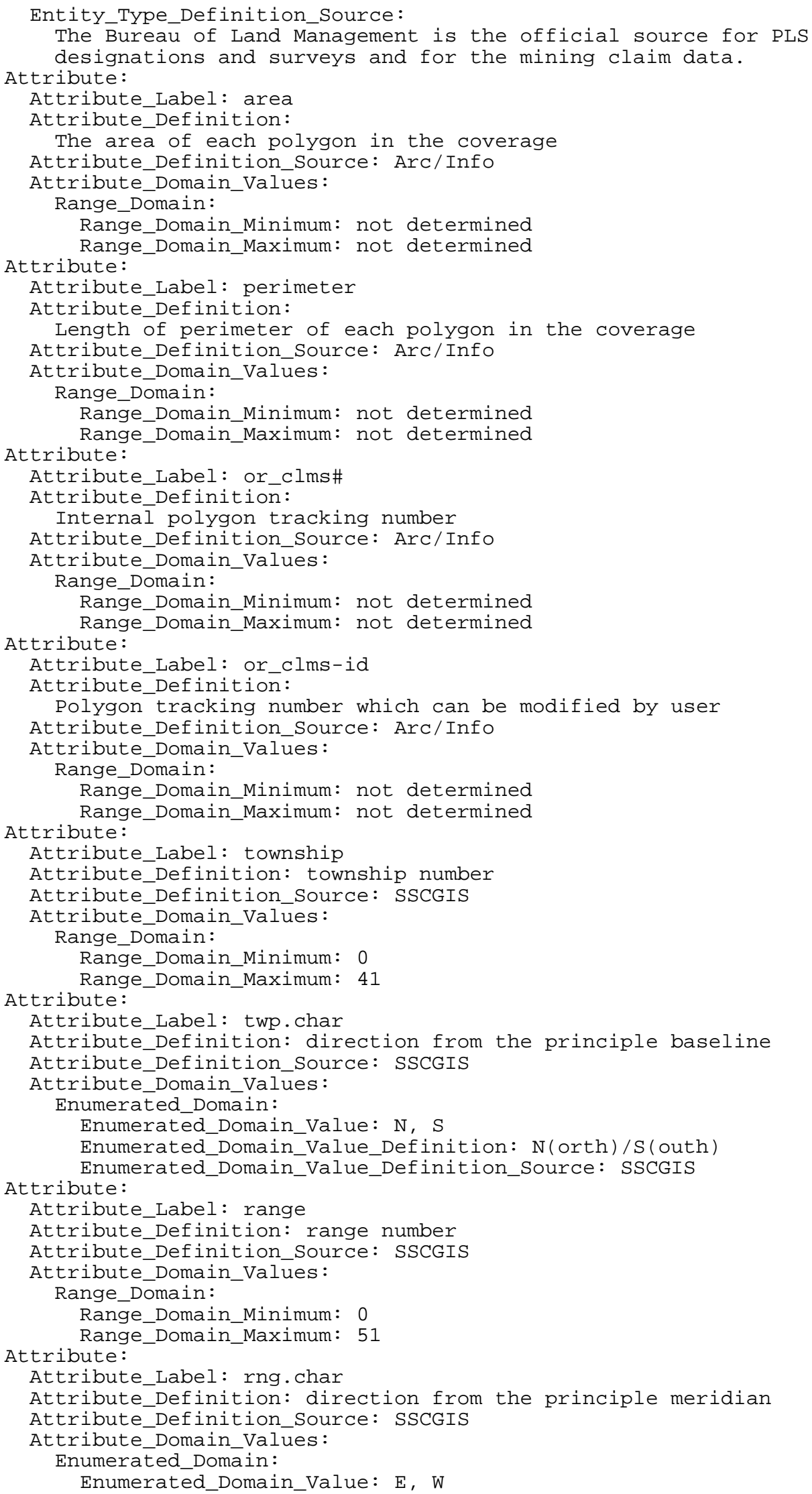




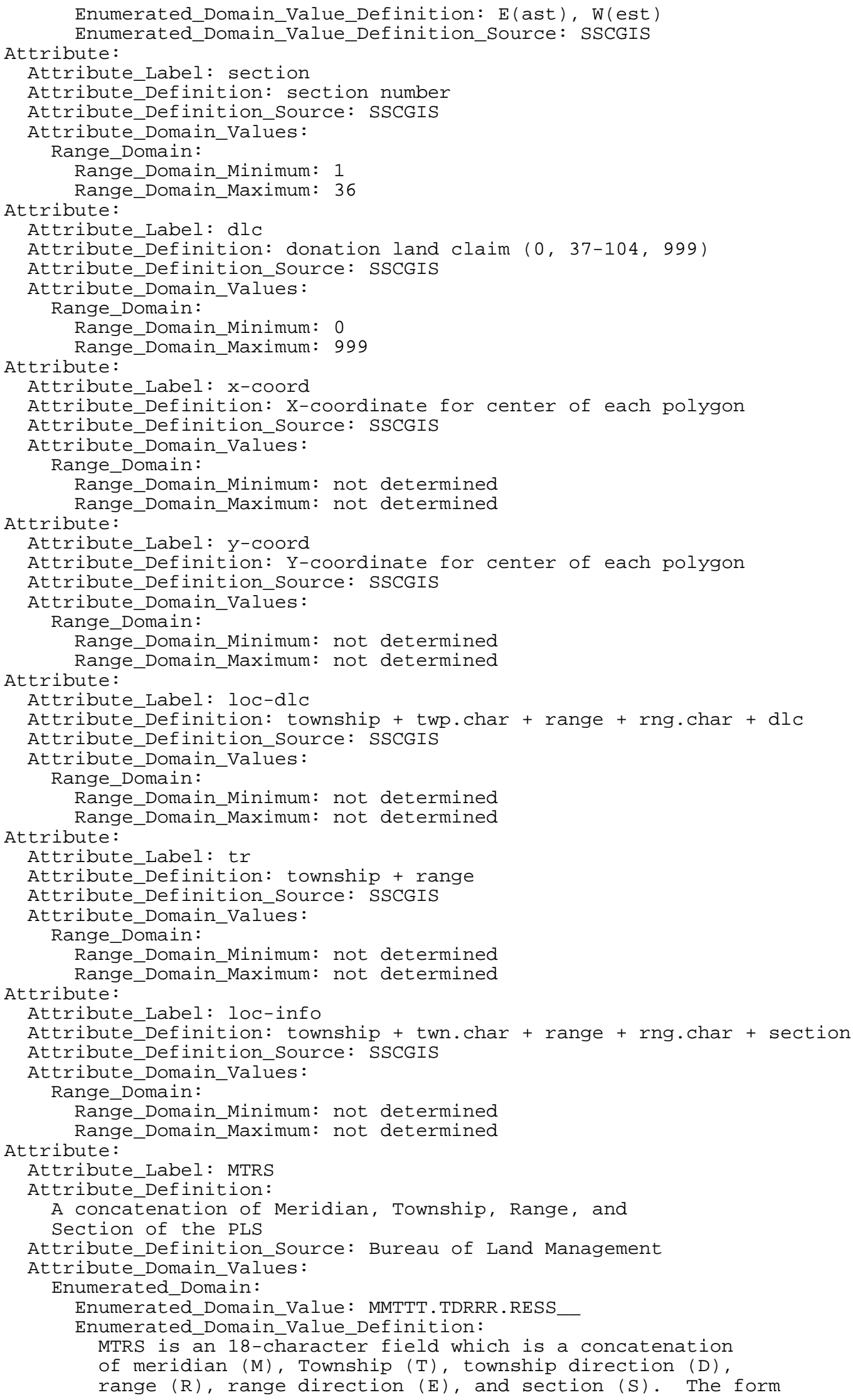


of the field is MMTTT.TDRRR.RESS_. The last two spaces were included in the beginning of the study but were not utilized.

MM = the FIPS code for meridian. FIPS stands for the Federal Information Processing Standard. The code for the meridian is:

33 - Willamette Meridian

TTT.T = BLM Township designation as 'TTT.T' may include a fraction of a Township. For example, Township 1 would be ' 1.0 '. Township 29.5 would be '_29.2'. The' '.2' is a 1/2 township.

$\mathrm{D}=$ BLM Township direction may be North (N) or South (S) .

RRR.R = BLM Range designation as 'RRR.R' which may include a fraction of a Range See Township (T) for example.

$\mathrm{E}=$ BLM Range direction may be East (E) or West (W).

$\mathrm{SS}=$ BLM Section number. For example, section 1 is ' 1 ' and section 35 is ' $35^{\prime}$. Generally the highest section number is 36 , but there are exceptions in several states.

Enumerated_Domain_Value_Definition_Source: Hyndman and Campbell, 1999

Distribution_Information:

Distributor:

Contact_Information:

Contact_Person_Primary:

Contact_Person: Paul Hyndman

Contact_Organization: U.S. Geological Survey

Contact_Position: Geologist

Contact_Address:

Address_Type: mailing and physical address

Address: W. 904 Riverside Avenue, Room 202

City: Spokane

State_or_Province: Washington

Postal_Code: 99201

Country: USA

Contact_Voice_Telephone: 509-368-3118

Contact_Facsimile_Telephone: 509-368-3199

Contact_Electronic_Mail_Address: phyndman@usgs.gov

Contact_Instructions: Main phone number is 509-368-3100

Resource_Description: Open-File Report 99-541

Distribution_Liability:

The U.S. Geological Survey (USGS) provides this data "as is."

The USGS makes no guarantee or warranty concerning the accuracy of

information contained in the geographic data. The USGS further makes no

warranties, either expressed or implied as to any other matter whatsoever, including, without limitation, the condition of the product, or its

fitness for any particular purpose. The burden for determining fitness for use lies entirely with the user. Although this data has been processed successfully on computers at the USGS, no warranty, expressed or implied, is made by the USGS regarding the use of this data on any other system, nor does the fact of distribution constitute or imply any such warranty.

In no event shall the USGS have any liability whatsoever for payment of any consequential, incidental, indirect, special, or tort damages of any kind, including, but not limited to, any loss of profits arising out of use of or reliance on the geographic data or arising out of the delivery, installation, operation, or support by the USGS.

Technical_Prerequisites: The user should have GIS software capable of reading Arc/Info files

Distributor:

Contact_Information:

Contact_Organization_Primary:

Contact Organization: U.S. Geological Survey Information Services

Contact_Address:

Address_Type: mailing and physical address

Address:

Open-File Reports 
Box 2586

City: Denver

State_or_Province: CO

Postal_Code: 80225

Country: USA

Contact Voice Telephone: 1-303-202-4200

Contact_Facsimile_Telephone: 1-303-202-4693

Resource_Description: Open-File Report 99-541

Distribution_Liability:

The U.S. Geological Survey (USGS) provides this data "as is."

The USGS makes no guarantee or warranty concerning the accuracy of

information contained in the geographic data. The USGS further makes no

warranties, either expressed or implied as to any other matter whatsoever, including, without limitation, the condition of the product, or its

fitness for any particular purpose. The burden for determining fitness for use lies entirely with the user. Although this data has been processed successfully on computers at the USGS, no warranty, expressed or implied, is made by the USGS regarding the use of this data on any other system, nor does the fact of distribution constitute or imply any such warranty .

In no event shall the USGS have any liability whatsoever for payment of any consequential, incidental, indirect, special, or tort damages of any kind, including, but not limited to, any loss of profits arising out of use of or reliance on the geographic data or arising out of the delivery, installation, operation, or support by the USGS.

Technical_Prerequisites: The user should have software GIS software capable of reading Arc/Info files.

Distributor:

Contact_Information:

Contact_organization_Primary:

Contact_Organization: U.S.G.S. Earth Science Information Office

Contact_Address:

Address_Type: mailing and physical address

Address: 904 West Riverside Avenue, Rm. 135

City: Spokane

State_or_Province: WA

Postal_Code: 99201

Country: USA

Contact_Voice_Telephone: 509-368-3130

Contact_Facsimile_Telephone: 509-353-2872

Contact_Electronic_Mail_Address: esnfic@mailmcan1.wr.usgs.gov

Hours_of_Service: $8: 00$ a.m. - 4:30 p.m. Pacific time zone

Resource_Description: Open-File Report 99-541

Distribution_Liability:

The U.S. Geological Survey (USGS) provides this data "as is."

The USGS makes no guarantee or warranty concerning the accuracy of

information contained in the geographic data. The USGS further makes no

warranties, either expressed or implied as to any other matter whatsoever, including, without limitation, the condition of the product, or its fitness for any particular purpose. The burden for determining fitness for use lies entirely with the user. Although this data has been processed successfully on computers at the USGS, no warranty, expressed or implied, is made by the USGS regarding the use of this data on any other system, nor does the fact of distribution constitute or imply any such warranty.

In no event shall the USGS have any liability whatsoever for payment of any consequential, incidental, indirect, special, or tort damages of any kind, including, but not limited to, any loss of profits arising out of use of or reliance on the geographic data or arising out of the delivery, installation, operation, or support by the USGS.

Technical_Prerequisites: The user should have software GIS software capable of reading Arc/Info files.

Metadata_Reference_Information:

Metadata_Date: $1 \overline{9} 990416$

Metadata_Review_Date: 19990820

Metadata_Contact:

Contact_Information:

Contact_Person_Primary:

Contact_Person: Paul Hyndman 
Contact_Organization: U.S. Geological Survey Contact_Position: Geologist

Contact_Address:

Address_Type: mailing and physical address

Address: W. 904 Riverside Avenue, Room 202

City: Spokane

State_or_Province: Washington

Postal_Code: 99201

Country: USA

Contact_Voice_Telephone: 509-368-3118

Contact_Facsimile_Telephone: 509-368-3199

Contact_Electronic_Mail_Address: phyndman@usgs.gov

Hours_of_Service: 8am to 4:30pm

Contact_Instructions: Main phone is 509-368-3100

Metadata_Standard_Name: FGDC Content Standards for Digital

Geospatial Metadata

Metadata_Standard_Version: FGDC-STD-001-1998

Metadata_Time_Convention: local time

Metadata_Access_Constraints: none

Metadata_Use_Constraints: none 